\title{
NATIONAL BIOMEDICAL TRACER FACILITY PLANNING AND FEASIBILITY STUDY
}

\author{
Richard A. Holmes, M.D. \\ Principal Investigator \\ Society of Nuclear Medicine \\ New York, New York
}

with assistance from the

U.S. Department of Energy - Isotope Production Program

\section{Prepared for the U.S. Department of Energy Under Grant Number DE-FG05-91ER61131}

\section{DISCLAIMER}

This report was prepared as an account of work sponsored by an agency of tne United States Government. Neither the United States Government nor any agency thereof, nor any of their employees, makes any warranty, express or implied, or assumes any legal liability or responsibility for the accuracy, completeness, or usefulness of any information, apparatus, product, or process disclosed, or represents that its use would not infringe privately owned rights. Reference herein to any specific commercial product, process, or service by trade name, trademark, manufacturer, or otherwise does not necessarily constitute or imply its endorsement, recommendation, or favoring by the United States Government or any agency thereof. The views and opinions of authors expressed herein do not necessarily state or reflect those of the Un $a d$ States Government or any agency thereof. 


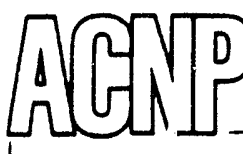

1101 Connecticut Avenue. N.W. • Sulte 700 - Washıngton. D.C. 20036

202.429 .5120

American

College of

Nuclear

Physicians

March 2, 1991

Admiral James D. Watkins, Secretary

Department of Energy

Forrestal Building

1000 Independence Avenue, SW

Washington, DC 20585

Dear Admiral Watkins:

We, the undersigned, are members of a National Biomedical Tracer Facility task force, which includes individuals from industry, and the scientific and academic communities as represented by the Society of Nuclear Medicine (SNM) and the American College of Nuclear Physicians (ACNP).

After almost one year of research and data collection, we are pleased to submit for your consideration a "National Biomedical Tracer Facility (NBTF) Planning and Feasibility Study." This proposed facility will promote and support radiation research, training, education, and isotope production. The NBTF will be pivotal in advancing American biomedical research and health care delivery into the 21 st century.

We urge the Department of Energy, the U.S. Congress, and the President of the United States to consider undertaking our recommendation to support the construction of the NBTF as soon as possible.

Sincerely,

Richard O. 20.mies

Richard A. Holmes, M.D.

Professor, Medicine, Radiology, Nuclear Engineering University of Missouri - Columbia

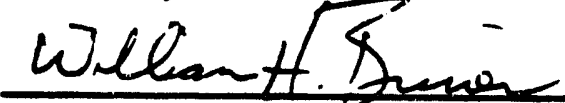

Capt. William Briner, (Ret.)

Associate Professor of Radiology

Duke University Medical Center

Chairman, Government Relations Com-

mittee

Society of Nuclear Medicine

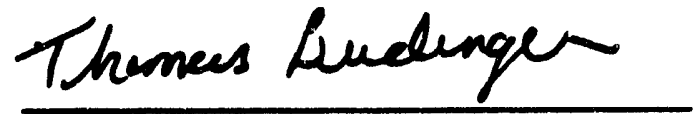

Thomas F. Budinger, M.D.

Lawrence Berkley Laboratory University of California - Berkley

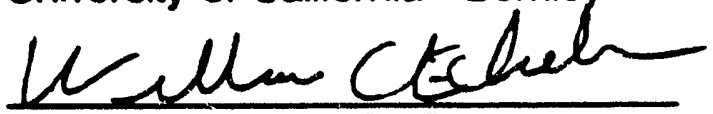

William Eckelman, Ph.D.

Department of Nuclear Medicine National Institutes of Health 
Letter to Admiral Watkins

March 2, 1991

Page 2

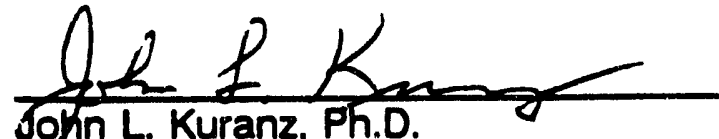

Join L. Kuranz, Ph.D.

Chairman of the Board

Medi-Physics Inc.

John McAfee, M.D.

Professor of Radiology

George Washington University Medical

Genter

i.

Darrell W. Mclndoe, M.D.

Nuclear Medicine Physician

Chairman - Government Affairs Committeo

American College of Nuclear Physicians

Hared Q. Q'Brien

Harold O'Brien, Jr., Ph.D.

Scientific Staff Member

Physics Division and Health, Safety, and

Environmental Division

Los Alamos National Laboratory

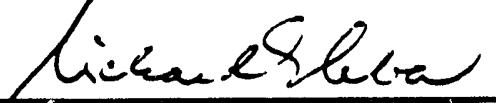

Richard Reba, M.D.

Professor of Radiology and Medicine

Direstor, Division of Nuclear Medicine

George Washington University Medical

Center
Niguenlalbikert

Wynn Yolkert, Ph.D.

Associate Career Research Scientist

Harry S. Truman VA Hospital

Professor of Radiology

University of Missouri - Columbia

Penry N. Wa gner, Jr., M.D.
Professor, of Medicire, Radiology and

Radiation Health Sciences

Johns Hopkins Medical Institutions

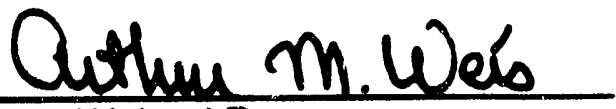

Arthur Weis, J.D.

Chairman and President

Capintec, Inc.

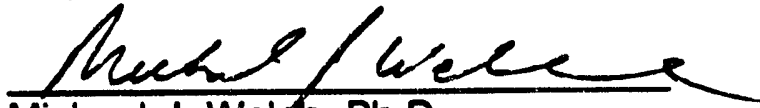

Michael J. Welch, Ph.D.

Professor of Radiology

Director, Division of Radiation Science

Washington University Medical School

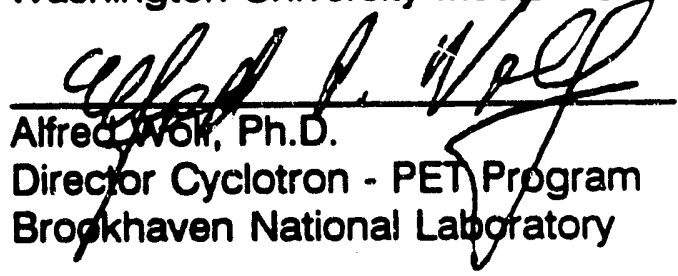




\section{TABLE OF CONTENTS}

JUSTIFICATION OF PROPOSAL $\ldots \ldots \ldots \ldots \ldots \ldots \ldots \ldots \ldots \ldots$

THE PRODUCTION FACILITY $\ldots \ldots \ldots \ldots \ldots \ldots \ldots \ldots \ldots \ldots \ldots$

Introduction ............................ 4

Accelerator Parameters/Radioisotope Requirements $\ldots \ldots \ldots \ldots \ldots \ldots 4$

Accelerator Recommendations . . . . . . . . . . . . . . . . . 6

Accelerator Facility Description $\ldots \ldots \ldots \ldots \ldots \ldots \ldots \ldots \ldots$

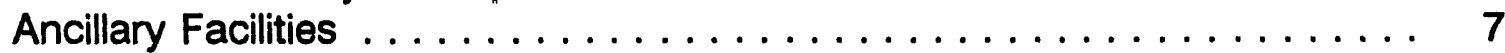

Infrastructure Requirements $\ldots \ldots \ldots \ldots \ldots \ldots \ldots \ldots \ldots$

Facility Cost .............................. 10

Facility Completion Schedule $\ldots \ldots \ldots \ldots \ldots \ldots \ldots \ldots \ldots \ldots \ldots 11$

Facility Staffing Requirements $\ldots \ldots \ldots \ldots \ldots \ldots \ldots \ldots \ldots \ldots \ldots$

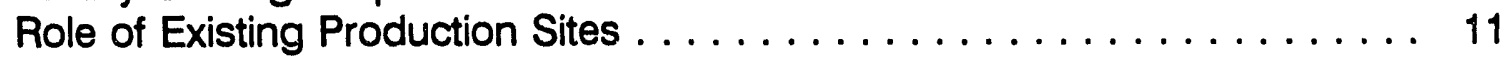

RESEARCH USING RADIOISOTOPES $\ldots \ldots \ldots \ldots \ldots \ldots \ldots \ldots \ldots \ldots$

Production Radioisotopes . . . . . . . . . . . . . . . . . . . 14

Research Radioisotopes $\ldots \ldots \ldots \ldots \ldots \ldots \ldots \ldots \ldots \ldots \ldots$

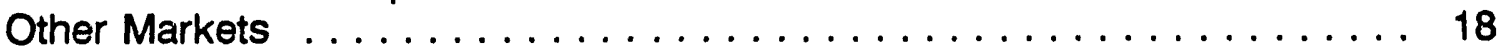

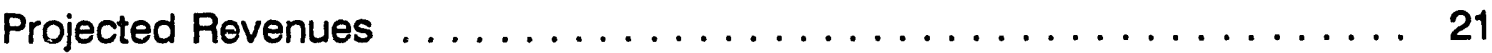

Targetry Research $\ldots \ldots \ldots \ldots \ldots \ldots \ldots \ldots \ldots \ldots \ldots \ldots \ldots \ldots \ldots$

SCIENTIFIC EDUCATION AND TRAINING $\ldots \ldots \ldots \ldots \ldots \ldots \ldots \ldots \ldots$

Proposed Structure of the Educational Program . . . . . . . . . . 24

Funding $\ldots \ldots \ldots \ldots \ldots \ldots \ldots \ldots \ldots \ldots \ldots \ldots \ldots \ldots \ldots \ldots \ldots \ldots \ldots, 25$

POSSIBLE SITE SELECTICN CRITERIA FOR THE NBTF $\ldots \ldots \ldots \ldots \ldots \ldots .27$

NATIONAL BIOMEDICAL TRACER FACILITY ADVISORY COMMITTEE . . . . . 28

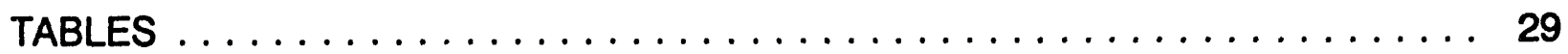

Table I. Comparison of $100 \mathrm{MeV}$ Accelerator Parameters .......... 30

Table II. Linac vs. Cyclotron Analysis . . . . . . . . . . . . . . 31

Table III. Facility Staffing Requirements ................. 32

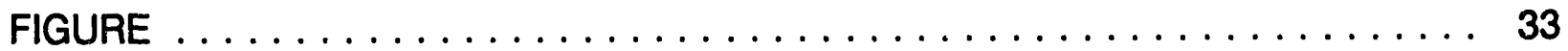

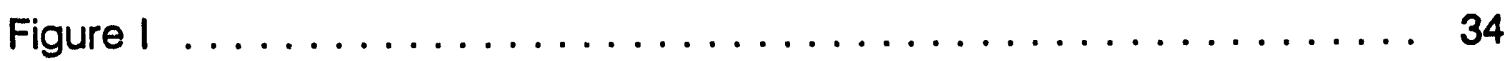

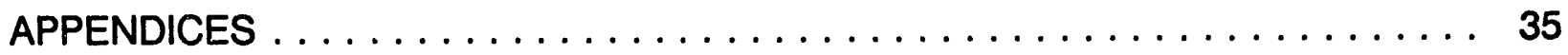

Acronyms/Documents Cited $\ldots \ldots \ldots \ldots \ldots \ldots \ldots \ldots \ldots \ldots$

Table of Elements . . . . . . . . . . . . . . . . . . . . . . . . . 37

Contributing to this Report $\ldots \ldots \ldots \ldots \ldots \ldots \ldots \ldots \ldots \ldots$ 


\section{JUSTIFICATION OF PROPOSAL}

The United States is a world leader and has initiated major advances in the application of radioactive materials in the health sciences. Nuclear medicine is the practice of using radioactive isotopes (radioisotopes, or radionuclides) for: 1) diagnostic imaging, 2) measurements of physiologic processes, and 3) treatment of disease. For example, the radioiodine therapy used to treat First Lady, Barbara Bush's Graves' disease is a nuclear medicine procedure. Radionuclide imaging has been widely used for diagnosing brain and heart disease, and for diagnosing and treating many types of cancer. Nuclear medicine has useful applications in practically every organ system of the body, and is used to evaluate patient response to therapy. An estimated one out of every three hospital patients in the United States undergoes a nuclear medicine procedure; an even greater number of nuclear medicine studies are performed in outpatients. To perform a nuclear medicine study, radioisotopes are attached to drugs. These radiopharmaceuticals are then administered to patients (in vivo procedures) for more than fifty different types of diagnostic tests, including bone, heart, lung, brain, thyroid, kidney, liver, gall bladder, and colorectal scanning. Other types of nuclear medicine procedures are performed using radioisotope tracer techniques on patient blood or urine samples (in vitro procedures) for clinical laboratory tests.

The patients who have been served by nuclear medicine, both in the United States and in most other countries around the world, have benefitted immensely from past support from the Atomic Energy Commission (AEC) and the Department of Energy (DOE). For the United States to retain its prominent role in the application of radioactive materials in medicine, it is essential that this nation provide a reliable source and supply of radioisotopes.

Unfortunately, despite our pioneering leadership in this field, we are now beholden to sources outside the United States for the necessary radionuclides to practice and advance the field of nuclear medicine. The reactor and accelerator facilities that produce radionuclides for nuclear medicine are facing several problems that adversely affect the supply of radioisotopes for health care. 
The deteriorating state of nuclear reactors at DOE national laboratories, coupled with the shutdown of the sole remaining commercial reactor in the United States that supplied radioisotopes for medicine ${ }^{1}$, has forced us to become dependent on foreign suppliers. In addition, the recent shutdown of the main reactor in Canada ${ }^{2}$ has jeopardized the supply of the most cornmon isotope used in nuclear medicine, technetium-99m ( ${ }^{99 m} \mathrm{Tc}$ ). A possible solution to this problem would be to develop methods of creating these radionuclides in particle accelerators instead of reactors.

The lack of a continuous supply of accelerator-produced radioisotopes poses another critical problem for nuclear medicine patients. Twenty years of DOE-sponsored research at Los Alamos National Laboratory (LANL) and Brookhaven National Laboratory (BNL) has shown that large DOE accelerators (at higher energies than available with commercial accelerators) provide the most efficient means of producing a number of medically important radioisotopes. The problem is that accelerator-based radioisotope programs at LANL and BNL depend on the parasitic use of physics research accelerators. Declining budgets in these physics research programs have severely restricted the operating time of these accelerators and, as a result, curtailed the supply of radioisotopes needed by nuclear medicine patients.

Under the present system, nuclear medicine researchers become dissuaded from pursuing some of their ideas for medical advances because of the uncertain supply of radioisotopes. In particular, these researchers are discouraged because a continuous supply of accelerator-produced radioisotopes has never been available in the United States. This capability was achieved years ago in several European countries, Japan and Canada, allowing their researchers to conduct pioneering work, some of which has led to significant breakthroughs in nuclear medicine.

In the recent past, the United States was the focal point for training in the nuclear sciences. Aspiring students came to this country to learn the science and technology of nuclear medicine. Our preeminence has eroded to such an extent that vacant positions for nuclear medicine scientists, physicians, and technologists are increasing. We face a critical shortage of undergraduate and graduate students, so that we have become increasingly dependent on foreign-trained students to fulfill existing needs. U.S. graduate students and faculty members in nuclear medicine often travel abroad to seek advanced study and training in nuclear medicine because research radioisotopes are more available in other countries.

1 Cintichem, Inc., Tuxedo, New York, reactor permanently shutdown April 4, 1990.

2 Nordion Inc. (formerly AECL), Ontario, Canada, reactor shutdown January 13, 1991. 
This nation urgently needs a dedicated national accelerator facility, a National Biomedical Tracer Facility (NBTF), to produce radioisotopes for nuclear medicine research and clinical practice. Two recent DOE documents (Los Alamos and HERAC reports) propose a major initiative for the DOE to establish an accelerator facility dedicated to the continuous production of radioisotopes for biomedical applications. This national resource, with both research and educational components, would provide the United States with the capability to compete in this rapidly developing field. In addition to the medical applications, please note that the NBTF would provide materials used by scientists working in many other fields, such as nutrition, genetics, molecular biology, pharmacology, drug development, nuclear physics, environmental chemistry and measurements, geology, and industrial manufacturing. Alternative methods for providing reactor-produced radioisotopes via accelerators deserve investigation. Such methods, if proven feasible, would provide environmentally preferred alternative methods of production. The NBTF would provide a national, and international, focal point for the education of the future scientists. 


\section{THE PRODUCTION FACILITY}

\section{INTRODUCTION}

Since its establishment in mid-1989, the DOE Office of Isotope Production and Distribution has examined the recommendations of the Los Alamos Report. and the Health and Environmental Research Advisory Committee (HERAC) Report. The main recommendation from these deliberations is for the DOE to establish an accelerator dedicated to biomedical radioisotope production. There is a compelling need for this NBTF to provide materials for optimal health care in the United States, and to ensure that this country regains its preeminent role in the science and technology of biomedical radioisotopes. Three complementary functions can justify the creation of the NBTF:

1. Production of radioisotopes for sale to radiopharmaceutical manufacturers, nuclear medicine facilities, and other markets.

2. Radioisotope production for nuclear medicine research and development.

3. Education and training.

\section{ACCELERATOR PARAMETERS/RADIOISOTOPE REQUIREMENTS}

Representatives of the nuclear medicine community, meeting at a DOE workshop in August 1988, evaluated present and future needs for accelerator-produced radioisotopes. Workshop participants concluded in the Los Alamos Report that approximately $90 \%$ of their radioisotope needs could be met by a machine that delivers a 70 million electronic volts (MeV), 500-microamp proton beam. The HERAC Report provides more quantification of radioisotope needs, and included isotopes that can be produced effectively only at higher energies. An accelerator facility with an upper energy limit of $100 \mathrm{MeV}$ and beam current of 750 to 1,000 microamps, could produce all important acceleratorproduced radioisotopes in current use, as well as those isotopes judged to have future potential value in medical research and clinical practice. We therefore recommend that the NBTF have a $100-\mathrm{MeV}$ proton beam accelerator with an extracted beam current of 750 to 1,000 microamps. 


\section{LINAC vs. Cyclotron Machine Descriptions}

Once the machine parameters, particularly the energy and beam current, have been resolved, the next issue is which type of accelerator -- linear accelerator (LINAC) or cyclotron -- would best serve the goals of the NBTF. A detailed technical comparison of LINAC, versus cyclotron parameters was carried out at the initially proposed $70 \mathrm{MeV}$. This information, assembled from commercial and DOE sources, is summarized in Table I. The comparison also is valid at $100 \mathrm{MeV}$. The cyclotron accelerates $\mathrm{H}^{-}$(negative hydrogen icnized) particles, whereas the LINAC can accelerate both $\mathrm{H}^{+}$(positive ionized hydrogen) and $\mathrm{H}^{-}$particles, simultaneously. Both types of accelerators can reach the desired energy. The cyclotron energy is continuously variable, but the LINAC is incrementally variable. Although continuously variable energy output from drift tube LINACs has been described in the patent literature, this technology is not standard practic . Beam currents for both technologies are comparable. The duty factor is $100 \%$ for the cyclotron and $1.5 \%$ to $3 \%$ for the LINAC; this has major ramifications for targeting. The flexibility of a cyclotron allows particle beams of different energies to be extracted simultaneously. Estimated costs for both machinas are comparable.

Two additional points should be considered when choosing between a LINAC and a cyclotron. The first is that cyclotron companies have manufacturing and operating experience with machines at $30 \mathrm{MeV}$ and higher. The proton LINAC manufacturers do not have such commercial experience. Secondly, because of the operational experience at $30 \mathrm{MeV}$, automated control has been demonstrated for the cyclotron. Although automated control should not be a problem for the commercial LINAC manufacturers, it could extend the delivery time for a LINAC because this feature is still in the development stage.

\section{Advantages of Cyclotron}

The advantages of the cyclotron are essentially the converse of the LINAC's, and include the relative simplicity of the hardware [one radio frequency (Rf) amplifier], the flexibility of the beam extraction and the DC beam output. Another advantage is the demonstrated automated control for the cyclotron operation. This is extremely important for routine and reliable operation of the facility. Lastly, the cyclotron would better serve the NBTF's educational mission because most proton accelerators in industrial and clinical settings are cyclotrons.

\section{Disadvantages of Cyclotron}

The major disadvantage of the cyclotron is the fixed maximum energy due to the electomagnetic stripping (no upgrade possible). While it is true that the cyclotron requires a lower base vacuum pressure to minimize machine activation, the cyclotron will reach this lower pressure with fewer pumps, thus minimizing maintenance. Also the use of carbon stripper foils for beam extraction from the cyclotron is considered a 
disadvantage, however, carbon stripper foils also will be required for the LINAC when operated in the $\mathrm{H}^{-}$mode.

\section{Advantages of LINAC}

Table II lists the advantages and disadvantages of the two accelerator technologies. The main advantages of the LINAC include the ready accessibility of energies up to $150 \mathrm{MeV}$ and simultaneous acceleration of $\mathrm{H}^{+}$and $\mathrm{H}^{-}$. Also, the very low machine activation is a desirable characteristic in light of the increased awareness of environmental, safety, and health issues.

\section{Disadvantages of LINAC}

Disadvantages of the LINAC include its equipment-intensive nature (5 or more Rf amplifiers), and the concomitant higher maintenance costs. Other disadvantages include the LINAC's incrementally variable energy mode. The high instantaneous power deposition on targets that results from pulse mode operation significantly complicates target design. The beamline switchyard that directs beams to targets could be quite complex.

\section{ACCELERATOR RECOHMENDATIONS}

Based on the foregoing xiscussion, we recommend using a cyclotron to satisfy the essential production, research, and educational missions of the NBTF. It would provide adequate energy and beam current capability, and the DC beam operation is essential to meet the NBTF mission. A cyclotron would also allow an ambitious construction and implementation schedule for the NBTF. The machine extracted beam energy should be $100 \mathrm{MeV}$, so that a beam of $\leq 92 \mathrm{MeV}$ can be delivered to targets. The beam energy should be variable down to $30 \mathrm{MeV}$. The beam current should be at least 750 microamps. This beam current regime would ensi ure adequate production yields of most radioisotopes produced with this facility, while minimizing the targeting problems associated with higher beam currents.

\section{ACCELERATOR FACILITY DESCRIPTION}

Figure 1 shows a conceptual layout of the accelerator vault and targeting caves. The accelerator vault is approximately $20 \mathrm{~m} \times 25 \mathrm{~m} \times 5 \mathrm{~m}$, shielded by $3 \mathrm{~m}$ of concrete. We envision four targeting caves (two for each extracted beam from the cyclotron), and three beam lines for each extracted beam. One beam line could serve as a production beam that goes to one target cave. There could be two additional beam lines for research. These beam lines would share a target cave. A mirror image of this setup would route the second extracted beam from the cyclotron. 
Beams could be diverted to the appropriate beam lines by a switching magnet. The external switching magnet is proposed for numerous technical reasons. Although additional stripping foils can provide multiple simultaneous beams from the cyclotron, this approach may not be cost effective because it complicates maintenance and decreases the facility's flexibility. With the external switching magnet, beam conditioning is simplified and machine activation is minimized. In addition, cost effectiveness is maximized because beam diagnostics and pumping are minimized. Lastly, because of beam conditioning and equipment requirements, facility maintenance costs are minimized. However, simultaneous high-intensity (for production) and low-intensity (for research) operation would not be possible with this scheme. It is instructive to note that both the lon beam Applications, Inc. (IBA) and the Ebco $30 \mathrm{MeV}$ cyclotrons, that have been visited by DOE personnel, utilize external switching magnets for multiple beams. This approach is designed to enhance the NBTF's flexibility.

The two production target caves are positioned as far from the labs and offices as possible. Two shielding walls, minimize radiation exposure to personnel in the facility. The production target caves also are positioned for ready access to hot cells. In this manner, target insertion and retrieval can be accomplished remotely, with automated delivery of irradiated targets through the corridor to the hot cells for processing. Each research target cave could house two beam lines. These caves are designed to handle low-activity targets. In addition, online radioisotope separation capability could be housed in one of these caves. This capability might give the NBTF additional flexibility because physical separation of radioisotopes can improve specific activity. The caves are designed with leaded glass windows and manipulators, so that target manipulations and online chemistry can be accomplished for research purposes.

This conceptual design also incorporates the accelerator control room, as well as laboratory and office space. The laboratories are for target preparation, low-level radiochemistry, and other physics and chemistry support required by the accelerator facility. The offices are for the support staff. A staging area for experimental set-up and breakdown is also essential to minimize accelerator downtime between experiments.

\section{ANCILLARY FACILITIES}

The multiple missions of the NBTF necessitate a number of ancillary facilities in addition to the accelerater and targeting building and asscriated vaults.

\section{Hot Cells}

The NBTF would produce established radioisoispes on a regular schedule under good manufacturing praciices. In many cases, this would require that a hot cell be dedicated to a single isotope or target. In addition, research radioisotope production and production research and development would add substantially to the variety of processing, requiring more hot cells in the NBTF complex. A minimum complex would 
contain 5 to 10 processing cells and on elarger general-purpose hot cell. The hot cell complex would also require two radiochemistry hoods to serve support functions as preparative/assay/staging areas. Significant cost savings would accrue if these facilities existed within the infrastructure of the host site.

\section{Radiochemistry Laboratories}

Targeting research, procedure development, low-level separations chemistry, analytical and quality assurance support for radioisotope distribution, and radiochemistry training would be conducted in 6 to 8 radiochemical laboratories. These laboratories would be segregated by activity levels to provide the necessary administrative controls for minimizing cross contamination and maximizing safety health and environment compliance. Two radiochemistry hoods would be necessary in each laboratory.

\section{Office Building}

The substantial training effort of the NBTF and the necessity for offices external to radiation areas dictate a minimum office comnlex of approximately $2000 \mathrm{sq}$. ft. This office complex would house both the permanent s:aif and visitors.

\section{Classrooms and Training Laboratories}

The training mission of the NBTF would require formal courses with laboratories for undergraduate and graduate students. Seminar rooms would be a necessary part of the NBTF. The ability to handle tracer quantities of radionuclides in the teaching laboratories is essential. It would be more economical to include such teaching laboratories within the infrastructure of the host site.

\section{Hot Machine Shop}

Target development, as well as accelerator and hot cell maintenance, would require a hot machine shop with appropriate mills and lathes. This would be a one-to-two person shop as well as a staff shop, and must be equipped for rapid response. This necessitates modern, computer-based machines and, to the extent possible, multi-purpose equipment. A staging area for prior check-out and alteration of machines destined for the hot cells would be necessary. The NBTF would also require the support of a larger shop, but this does not have to be part of the facility itself and will be discussed in the Infrastructure Requirements Section. 


\section{Waste Handling Capabilities}

Varying degrees of dedicated radioactive waste handling would be required as part of the NBTF. In a minimum configuration, volume reduction, neutralization, solidification, and other pretreatments need to be performed inside a hot cell. Packaging areas inside and outside of the hot cells are also required. Overhead cranes for moving waste trainsport casks can provide general support to the hot cell complex. A transport or truck bay is necessary in close proximity to the waste handling area. This area can also provide transport access to the shipping area.

\section{INFRASTRUCTURE REQUIREMENTS}

Infrastructure requirements for the NBTF are discussed below. While it is true that these functions could be developed in support of the NBTF, it would save operating and capital costs to have these facilities and capabilities available from the organization that operates the NBTF. This would not only minimize costs associated with these functions, but also may avoid potential permitting problems and probably shorten start-up time.

\section{Heavy Machine Shop}

O. riation of this facility would be hardware-intensive. It would require machining and fabrication of parts for beam lines, target insertion and retrieval mechanisms, and other required hardware. On-site machine shops would be a useful complement to the NBTF.

\section{Waste Disposal Capabilities}

One of the most important infrastructure requirements would be the waste disposal facility. The NBTF would produce some high radioactive liquid wastes, mixed wastes, and low-level radioactive solid wastes that must be handled properly and disposed of in an environmentally acceptable manner. Experience with waste minimization activities would be required. This necessarily requires expertise in separations chemistry and radiochemistry, in addition to waste and environmental management.

\section{Health Physics Expertise, Security}

Irradiated targets are highly radioactive. Handling of these targets from the accelerator, transport into the hot cells, chemical processing in the hot cells, packaging and shipping of radioisotopes, and use of radioisotopes in research all require dedicated health physics professionals to ensure the health and safety of NBTF personnel. Professional health physics coverage is especially important for the radioisotope sales and distribution mission because production and shipping schedules must be met routinely and reliably. Police and fire protection are also necessary. 


\section{Radioisotope Sales and Distribution Functions}

The radioisotope sales and distribution activities would require certain administrative functions that should be available as part of the organization infrastructure. Necessary administrative functions would include radioisotope marketing, radioactive materials shipping, accounting and financial capabilities, inventory control, compliance with Food and Diug Administration (FD,A) good manufacturing practices and administrative requirements, and customer reiations.

\section{FACILITY COST}

\section{Accelerator}

The cost for either the $100 \mathrm{MeV}$ cyclotron or linear accelerator is in the vicinity of 10 million to $\$ 12$ million. Costs generated for the $100 \mathrm{MeV}$ cyclotron were extrapolated by DOE staff from the $30 \mathrm{MeV}$ experience.

\section{Accelerator Vault and Building}

Cost estimates for the vault, beamiines, building required to house the accelerator, target caves, and ancillary equipment are difficult to estimate because of lack of prior experience with such a facility. However, EBCO Technologies' experience with a similar building to house a 30 iMeV cyclotron at the Canadian Tri-University Meson Facility (TRIUMF) site is instructive. The accelerator cost approximately $\$ 3.5$ million, and the vault and building cost approximately $\$ 3.5$ million. If this experience extrapolates, it can be expect that the vault and associated building costs would be in the vicinity of $\$ 13$ million for $100 \mathrm{MeV}$ accelerator of the NBTF. A detailed design for this facility must be available before further refinements of the cost estimate for this part of the project can be estimated.

\section{Ancilląry Facilities}

Costs for these facilitiss would be dependent on the site for the NBTF. Some or all of the ancillary facilities required by thie NBTF may be preexisting at cərtain sites. In fact, such criteria are discussed in "possible Site Selection Criteria" of this study.

\section{Cost Estimate}

The budget of appoximately $\$ 38$ million is expected to cover:

1. machine design, construction and installation,

2. architecture and engineering of the building to house the machine and ancillary facilities and

3. construction of the facility and provision for the essential equipment. 


\section{FACILITY COMPLETION SCHEDULE}

\section{Construction Schedule}

The time-frame for construction of the envisioned NBTF, with a $100 \mathrm{MeV}$ acceierator, is based on the actual experience of the EBCO Technologies $30 \mathrm{MeV}$ project at TRIUMF. This project is the best available basis for comparison. No other comparable experience in planning anú building an experimental medical radioisotope production and research facility has been identified.

The TRIUMF schedule was estimated at 20 months starting after detailed design and guing through the final inspection (Title III) of the finished cyclotron, laboratories, and associater, support activities. Since extension of a similar construction to higher energy in some ways presents no significant changes in concept (i.e., office and support buildings), we need only consider the schedule time as being affected by scale. Construction of a higher energy facility does include some areas of significant uncertainties (i.e., construction of beam lines and target areas) regarding the time of fabrication, and these can only be inferred at this time.

Combining these considerations, it is estimated that it would take approximately 40 to 44 months to build the $100 \mathrm{MeV}$ facility. The initial planning and decision stage is estimated to require 12 to 18 months, giving a total project duration of approximately 58 months.

\section{FACILITY STAFFING REQUIREMENTS}

The staffing requirements for the NBTF to meet the multi-faceted production, :esearch, and educational missions are estimated in Table III. These estimates were made assuming that appropriate support and infrastructure personnel would be available at the NBTF site. Therefore, personnel estimates are only those required for direct operation of the facility.

\section{ROLE OF EXISTING PRODUCTION SITES}

Currently, DOE provides for accelerator production of biomedical radionuclides at BNL and LANL. At BNL, the radioisotopes are produced in the Brookhaven LINAC Isotope Production Facility (BLIP), which is operated in conjunction with the BNL Alternating Gradient Synchrotron. BLIP utilizes a proton beam of $200 \mathrm{MeV}, 60$ microamps. Although BLIP occasionally has operated for up to 32 weeks per year, it normally operates for only 13 to 18 weeks annually, resulting in a rather erratic supply of needed radionuclides. At LANL, accelerator-produced radioisotopes are created in the Los Alamos Meson Physics Facility (LAMPF), a linear accelerator of $800 \mathrm{MeV}, 1.1$ milliamps, and has operated for up to 6 months per year. Unfortunately again, it now runs for about 20 weeks per year, resulting in an all-too-intermittent supply of radioisotopes needed for biomedical research and health care. 
The reason for the limited operating schedules of these machines is that operation is dictated by high-energy physics research needs and physics research budgets. By judicious scheduling, the BLIP and LAMPF operating schedules do not overlap. However, their combined operating time does not add up to a full year, and does noi, therefore, assure continuous avaiiability of needed radioisotopes -- many of which are short-lived and increasingly utilized ir, important medical applications. At this time, future operating schedules of BLIP and LAMPF are uncertain, inasmuch as these operating schedules are wholly dependent on future availability of funds for physics research. Also, the operating costs of BLIP and LAMPF are such that the revenues generated from the sale of radioisotopes are insufficient to support operation of these facilities.

The problem, therefore, is how the supply of essential accelerator-produced radioisotopes can be assured on a continuous basis, and at affordable costs. This was examined in the DOE Los Alamos Report and considered further in the HERAC Report. Each of these two reviews concluded that this nation should not continue to rely on uncertain physics program budgets for the supply of essential radioisotopes for medical and other applications. The Los Alamos and HERAC Reports have, therefore, both recommended that DOE should build and operate a dedicated medical radioisotope production accelerator, the NBTF.

Though the future of these two accelerators is uncertain in view of new larger machines being planned and built for high-energy physics, it is significant that a dedicated lowerenergy production accelerator would complement the spallation capabilities of BLIP and LAMPF-IPF rather than make them unneicessary. Moreover, these machines can supply the demand year-round for the important radioisotopes that have long half-lives.

There are a substantial variety of radioisotopes now effectively produced at high-proton energy via spallation reactions, such as aluminum-26 $\left({ }^{26} \mathrm{Al}\right)$, magnesium-28 $\left({ }^{28} \mathrm{Mg}\right) /{ }^{28} \mathrm{Al}$, cadmium-109 $\left({ }^{109} \mathrm{Cd}\right)$, sodium-22 $\left({ }^{22} \mathrm{Na}\right)$, calcium-47 $\left({ }^{47} \mathrm{Ca}\right)$ and selenium-72 $\left({ }^{72} \mathrm{Se}\right)$. Moreover, both of the existing high-energy production accelerators can provide important targeting and processing data, pertinent to production of radioisotopes on a dedicated accelerator during the 1990-1995 time period. It is apparent that the Brookhaven and Los Alamos radioisotope production facilities would continue to serve a vital need for accelerator-produced research isotopes as long as they continue to operate at their present levels.

In addition to the few radioisotopes described above that are best produced at higher proton energies, a few isotopes requiring other particle acceleration would not be available from the NBTF. Although it is widely recognized that astatine-211 $\left({ }^{211} \mathrm{At}\right.$ ) has great potential for radiotherapy, it can only effectively be produced with alpha particle bombardment. Unfortunately, the parameters for the proposed NBTF accelerator are not compatible with alpha particle acceleration. The technical criteria for the NBTF, however, cannot revolve around one radioisotope. 


\section{RESEARCH USING RADIOISOTOPES}

The subject of research using radioisotopes has been discussed in the review of the HERAC Report. The availability of radionuclides for various research programs is of immense importance. New radionuclides are needed for many biomedical applications, both in diagnosis and therapy. One particularly important radionuclide, which is readily available from European national facilities, is iodine-123 $\left({ }^{123} \mathrm{I}\right)$. For many applications, ${ }^{123} \mathrm{I}$ is the ideal radionuclide. Radiopharmaceuticals labeled with ${ }^{123}$ | are critical to the understanding of neurological diseases (including Alzheimer's disease) as well as for myocardial and tumor imaging. To date, investigators in the Ur.ted States have been frustrated and reluctant to exploit the clinical use of ${ }^{123}$, since it is not routinely available and the costs remain quite high. A reliable U.S. source for this radinnuclide must be developed.

Positron emission tomography (PET) has been pioneered in the United States. Positron emitting radionuclides -- such as copper-64 $\left({ }^{64} \mathrm{Cu}\right)$ and copper-62 $\left({ }^{62} \mathrm{Cu}\right)$-- play a significant role in the diagnusis and understanding of various diseases states. New copper radiopharmaceuticals for the study of cerebral and myocardial blood flow are under development, and at least one of these new drugs, copper-PTSM, is the subject of clinical trials. The combination a medium half-life $\left({ }^{64} \mathrm{Cu}, 12.7\right.$ hours) and a short half-life $\left({ }^{62} \mathrm{Cu}, 9.7\right.$ minutes obtainec $40 ., 1$ zinc-62 $\left.\left({ }^{62} \mathrm{Zn}\right)\right)$ would allow for important studies on the effect of therapies.

One can imagine a patient with chest pains being admitted to the hospital and having the long half life tracer administered. This tracer would remain trapped in the myocardium and provide a map of blood flow to the muscle as it was during the moment of radiopharmaceutical injection. After various therapies, the patient could be moved to the imaging suite to obtain the ${ }^{64} \mathrm{Cu}$ heart scan. Then the patient could be injected with a ${ }^{62} \mathrm{Cu}$-labeled radiotracer and imaged again to show blood flow in the heart after therapy. These types of studies would be valuable in the evaluation of new therapeutic regimens for heart disease. Such studies could only be carried out if tracers were available from a national or regional facility.

Research on radiolabeled monoclonal antibodies, both for diagnosis and therapy, is likely to grow at a rapid pace. There will be a need for better radionuclides for diagnostic imaging and treating the brain, heart and malignant tumors. Promising isotopes include ruthenium-97 ( $\left.{ }^{97} \mathrm{Ru}\right)$, lead-203 $\left({ }^{203} \mathrm{~Pb}\right)$, bromine-75 $\left({ }^{75} \mathrm{Br}\right),{ }^{61} \mathrm{Cu},{ }^{64} \mathrm{Cu},{ }^{67} \mathrm{Cu}$, cobalt-55 $\left({ }^{55} \mathrm{Co}\right)$, zirconium-89 $\left({ }^{89} \mathrm{Zr}\right)$, and arsenic-72 $\left({ }^{72} \mathrm{As}\right)$, for planar imaging, single-photon emission computed tomography (SPECT) or PET techniques. Demand for radionuclides such as indium-111 $\left({ }^{111} \mathrm{In}\right)$, gallium-67 $\left({ }^{67} \mathrm{Ga}\right),{ }^{68} \mathrm{Ga},{ }^{23} \mathrm{I}$, fluorine-18 $\left({ }^{18} \mathrm{~F}\right)$, will also continue. There is a special need for high-specific-activity ${ }^{111} \mathrm{In}$, free of trace metal 
contaminants, for labeling monoclonal antibodies and other proteins; this type of ${ }^{111}$ In is not readily available on a commercial basis. ${ }^{96} \mathrm{Tc}$, if available, would prove invaluable in experimental comparisons (in animal studies) with ${ }^{99 \mathrm{~m}} \mathrm{Tc}$-labeled radiopharmaceuticals. For radioimmunotherapy ${ }^{131}$ I still will be used, but many other radionuclides -- such as scandium-47 $\left({ }^{47} \mathrm{Sc}\right)$ and ${ }^{67} \mathrm{Cu}$-- are being studied for this application. Future availability of many of these radionuclides will require high-energy nuclear reactions in an accelerator that can economically produce large quantities of these radionuclides with high-specific activity.

A number of short-lived radionuclide generator systems have been identified recently and will require continued development. Some are already undergoing investigation and evaluation, including: strontium-82 $\left({ }^{82} \mathrm{Sr}\right) /$ rubidium-82 $\left({ }^{82} \mathrm{Rb}\right)$, mercury $-195\left({ }^{195} \mathrm{Hg}\right) /$ gold$195\left({ }^{195} \mathrm{Au}\right)$, osmium-191 $\left({ }^{191} \mathrm{Os}\right) /$ /iridium-191 $\left({ }^{191} \mathrm{~m} / \mathrm{r}\right)$, tungsten-178 ( $\left.{ }^{178} \mathrm{~W}\right) /$ tantalum-178 $\left({ }^{178} \mathrm{Ta}\right)$, and ${ }^{109} \mathrm{Cd} / \mathrm{silver}-109 \mathrm{~m}\left({ }^{109 \mathrm{~m}} \mathrm{Ag}\right)$. The chemistry of separation for a number of these systems requires further development before clinical applications can be tried. Other radionuclide generator systems -- such as ${ }^{90} \mathrm{Sr} / \mathrm{yttrium}-90\left({ }^{90} \mathrm{Y},{ }^{72} \mathrm{Se} /{ }^{72} \mathrm{As}\right.$, and ${ }^{212} \mathrm{~Pb} /$ bismuth-212 $\left({ }^{212} \mathrm{Bi}\right)$ could be useful for monoclonal antibody immunotherapy, but further research will be required to validate their utility.

\section{PRODUCTION RADIOISOTOPES}

\section{Nuclear Medicine Market}

Many radionuclides can be produced on a $100 \mathrm{MeV}$ accelerator. [Research isotopes will be discussed in the next section, and continued production of those isotopes requiring higher energy spallation reactions was discussed in the section entitled "Role of Existing Production Sites."]

${ }^{82} \mathrm{Sr} /{ }^{82} \mathrm{Rb}$-. The demand for this isotope was stressed in the Los Alamos Report and the best estimate is that the current demand is one curie per month. FDA granted new drug application (NDA) approval for the clinical use of the ${ }^{82} \mathrm{Sr} /{ }^{82} \mathrm{Rb}$ generator for PET myocardial perfusion imaging in December 1989; therefore, the demand for ${ }^{82} \mathrm{Sr}$ is expected to increase rapidly as its use becomes integrated into existing PET centers. This development, coupled with the expected growth in the number of PET centers, should increase the demand dramatically.

${ }^{68} \mathrm{Ge} /{ }^{68} \mathrm{Ga}$-- Germanium-68 $\left({ }^{68} \mathrm{Ge}\right)$ is important for the future of PET because it is needed to generate the transmission images to correct for attenuation. Demand is based on the expected growth of PET centers, but excessive price increases could cause a bottleneck in PET use. As the use of PET continues to grow, the development of PET agents using ${ }^{68} \mathrm{Ga}$ will likely increase demand for this radionuclide. 
${ }^{67} \mathrm{Cu}$-- Current demand for ${ }^{67} \mathrm{Cu}$ is 600 millicurries per month (mCi/month). However, the availability of a continuous supply could bring several drug companies into the market and could escalate demand considerably by 1995 . With a reliable supply of ${ }^{67} \mathrm{Cu}$, continued progress in cancer treatment using monoclonal antibodies will contribute to a growing demand. It is too early to predict other radiopharmaceuticals or new agents containing ${ }^{67} \mathrm{Cu}$ that might prove useful in clinical medicine, but considering its desirable half-life, beta-decay for therapy, and gamma emissions for imaging, the market by the year 2000 could be substantial. Without a dedicated facility, ${ }^{67} \mathrm{Cu}$ radiopharmaceutical development will not progress.

123 I.. There is a large existing market for this radionuclide. It is primarily used as a SPECT brain imaging agent. There currently are commercial suppliers of this material, but the major source for U.S. hospitals is a Canadian manufacturer. Many patients in this country who could benefit from ${ }^{123}$ I imaging studies do not have these tests done because the use of ${ }^{123}$, in clinical practice has been impeded by lack of routine availability and high cost. With $100 \%$ enriched xenon-124 ( ${ }^{124} \mathrm{Xe}$ ) and $25.9 \mathrm{MeV}$ protons, a thick-target yield of $15.4 \mathrm{mCi} / \mu \mathrm{Ah}$ is obtained 6.6 hours after end of bombardment.

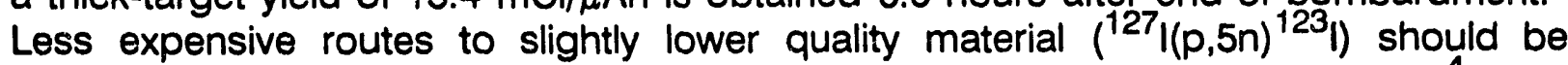
investigated. The literature indicates a production rate of $3 \mathrm{mCi} / \mu \mathrm{Ah}$ at $57.5 \mathrm{MeV}{ }^{4}$ Both these objectives -- increased availability and lower cost -- could be accomplished with the proposed DOE dedicated facility.

${ }^{127} \mathrm{Xe}$-- There was a continuing demand for 3 to $4 \mathrm{Ci} /$ month of this radioisotope when Brookhaven and Los Alamos produced it. When funding difficulties and personnel reductions forced Los Alamos to discontinue producing ${ }^{127}$ Xe, the lack of a continuous supply prompted the radiopharmaceutical industry to abandon this radioisotope. Many clinicians believe that this radioisotope is superior to ${ }^{133} \mathrm{Xe}$ in ventilation lung studies.

${ }^{57}$ Co -- This radioisotope is used extensively in nuclear medicine as an energy source for calibrating intaging instruments. Currently, there is a critical requirement for this material. Other applicutions for ${ }^{57} \mathrm{Co}$ are described later. Industrial sources place current demand in excess of $8 \mathrm{Ci} /$ year. Production of this radioisotope using the DOE dedicated facility should be given a high priority.

$3 \quad$ Radiochemistry (Acta). 41:1(1987).

$4 \quad$ Joumal of Nuclear Medicine. 13(1972):729. 


\section{RESEARCH RADIOISOTOPES}

It is anticipated that a substantial fraction of the beam from the NBTF facility would be made available for research and development activities and to produce research radionuclides. A listing of research radioisotopes that could receive initial emphasis at the NBTF follows. This is by no means an exhaustive list, but simply emphasizes the findings from the Los Alamos and HERAC Reports.

${ }^{109} \mathrm{Cd} /{ }^{109} \mathrm{Ag}$ - It would be difficult, even with the NBTF, to meet the current ${ }^{109} \mathrm{Cd}$ X-ray source demand within the nuclear medicine community. There is an intense interest in investigating the use of the daughter nuclide $\left({ }^{109} \mathrm{Ag}\right)$ in heart blood flow studies, particularly in infants and young children.

${ }^{72}$ Se/ ${ }^{72}$ As -- This generator has great potential for PET research applications. No data were found regarding lower energy proton production of ${ }^{72} \mathrm{Se}$. Cross-section measurements on an arsenic target need to be performed.

${ }^{52} \mathrm{Fe}$-- Iron-52 is a short-lived $(8.28 \mathrm{hr})$ positron emitter $(0.80 \mathrm{MeV})$ with substantial potential as a PET research isotope. It can be made effectively using spallation reactions on targets such as nickel, manganese, or copper. It also can be produced by bombardment of manganese targets with lower-energy protons.

${ }^{178} \mathrm{~W} /{ }^{178} \mathrm{Ta}$-- Tantalum-178 is a short-lived, low-energy gamma-emitter witi potential as a nuclear medicine imaging agent. The ${ }^{178} \mathrm{~W}$ parent of this radioisotope can be produced with great efficiency by bombardment of a tantalum target with $34 \mathrm{MeV}$ protons.

74 As -- This is another positron-emitting isotope with potential biomedical applications. Proton production with the beam using enriched ${ }^{74} \mathrm{Ge}$ seems possible. Targeting, cross-section measurements, and processing research and development is necessary before exploring any biomedical applications of this radionuclide.

$77 \mathrm{Br}$-- Bromine-77 has potential for monoclonal antibody labeling, and can be produced in the 15 to $30 \mathrm{MeV}$ proton range with reasonable efficiency on copper selenite targets. Research and development into target/process optimization and applications research could be effectively performed using the proposed dedicated accelerator.

${ }^{97} \mathrm{Ru}$-- Ruthenium-97 has potential as a gamma-camera imaging radioisotope, primarily when attached to monoclonal antibodies. It can be efficiently produced at energies greater than $70 \mathrm{MeV}$ on high-purity rhodium foils or on rhodium(III) chloride targets. BNL has developed its production and makes it available during BLIP operating periods. Additional target/process and applications research and development should be investigated at the NBTF. 
${ }^{88} Y$.- Yttrium - 88 has been substituted for ${ }^{90} Y$ in the development of cancer tumor therapy. The ${ }^{88} \mathrm{Y}$ can be produced efficiently with low-energy protons at the NBTF.

${ }^{7}$ Be - Berylium-7 has been used in berylliosis studies and has physics applications as well. Cross-section measurements for production of ${ }^{7} \mathrm{Be}$ at proton energies less than $70 \mathrm{MeV}$ on a carbon target have been made. It is feasible to produce ${ }^{7} \mathrm{Be}$ on the proposed $100 \mathrm{MeV}$ machine.

${ }^{62} \mathrm{Zn}$-- Zinc - 62 is the parent of ${ }^{62} \mathrm{Cu}$, a positron-emitting radionuclide with a 9.74-minute half-life. Because of its short half-life and the diverse chemistry of copper ${ }^{62} \mathrm{Cu}$ is an attractive radionuclide for labeling PET radiopharmaceuticals. New ${ }^{62} \mathrm{Cu}$ radiopharmaceuticals for the study of cerebral and myocardial blood flow are under development, and at least one ( ${ }^{62}$ Cu-PTSM) is in early clinical trails. Although results with generator-produced ${ }^{62} \mathrm{Cu}$ have been encouraging, a reliable supply of ${ }^{62} \mathrm{Zn}$ will be required to make the ${ }^{62} \mathrm{Zn} /{ }^{62} \mathrm{Cu}$ generator system. A PET facility making routine use of ${ }^{62} \mathrm{Cu}$ might require three $500-$ to $1000-\mathrm{mCi}$ shipments of ${ }^{62} \mathrm{Zn}$ per week.

${ }^{64} \mathrm{Cu}$-- Copper-64 decays by emission of a low-energy positron (18\%) with a half-life of 12.7 hours. The relatively long half-life makes it attractive for PET applications that require prolonged data collection or long delays between injection and imaging. Copper-64 shows promise, for example, for labeling monoclonal antibodies used in targeted radiotherapy. Some research PET facilities have used ${ }^{64} \mathrm{Cu}$ in preliminary studies aimed at screening and evaluating potential radiopharmaceuticals to be labeled with ${ }^{62} \mathrm{Cu}$.

${ }^{61} \mathrm{Cu}$-- Copper-61 is a positron-emitter that $\mathrm{m}$ ight find use in research and clinical PET studies, if a reliable supply existed. Its 3.4-hour half-life would allow its use as a radiolabel for monoclonal antibodies. Copper-61 could also be used to labe! ULu-PTSM for PET studies of tissue perfusion in instances where rapid imaging following injection is not feasible.

Many of the larger-volume radioisotopes listed in the previous section are used in the research and development of new radiopharmaceuticals, and are categorized as revenue isotopes because of an established demand. This does not minimize the importance of research radioisotopes to the nuclear medicine research community. For example ${ }^{68} \mathrm{Ge} /{ }^{68} \mathrm{Ga}$ is primarily used as a source to calibrate PET scanners for uniformity and transmission attenuation corrections. However, new PET agents incorporating the ${ }^{68} \mathrm{Ga}$ daughter present a growing area of research interest. Similarly, no licensed agents containing ${ }^{67} \mathrm{Cu}$ are yet available to the clinician, and all of the demand for this radioisotope is for research studies. As demand for a research radionuclide grows and production and processing are finalized, regular distribution schedules will naturally develop. This will allow for healthy maturation of a variety of new radiopharmaceuticals and for the continued development of nuclear medicine procedures that will improve health care for U.S. patients. 
Research and development of targeting, processing and separations, and product characterization are integral parts of the core research effort at the proposed NBTF. Equally important is the need for strong radiopharmaceutical development and labeling research programs. This parallel and integrated effort will help build the market for new isotopes and greatly enhance the core research and training emphasis at the NBTF.

\section{OTHER MARKETS}

It is important to realize that the nuclear medicine community is not the only user of radioisotopes produced by DOE facilities. Scientists in a wide variety of disciplines use radionuclides in their research. These isotopes are used to study biochemical processes in both healthy and diseased cells, and to investigate the mode of action and environmental fate of pesticides. Radionuclides are useful to trace geochemical pathways and assess models of elemental economies within the earth's ecosystem. They have been effectively used to evaluate and monitor environmental protection and clean-up systems. Several nuclides are employed as $\mathrm{x}$-ray sources for analytical and medical applications. The nuclear power industry depends upon specific radioisotopes for the calibration and quality assı: ance of their radioassay instruments and procedures. Other industries use radioactive tracer materials to develop and evaluate chemical processes. Physicists performing Mossbauer studies and investigating the origins of the universe use DOE produced radioisotopes in their research.

Some of these applications use the same radioisotopes used in nuclear medicine. Evaluating the importance of any given isotope to other scientific disciplines and establishing production priorities for the NBTF is difficult. Factors such as production efficiency, demand, importance to national security, etc., all enter into the decision-making process. Listed below are some radionuclides with important applications in other scientific disciplines. This list is not all-inclusive; it is meant to demonstrate the importance of considering other radioisotope markets outside of nuclear medicine.

${ }^{73}$ As -- Three years ago, the United States Geological Survey (USGS) expressed an interest in ${ }^{73} \mathrm{As}$ as an environmental tracer for investigating arsenic contamination by mining operations. This radioisotope was being recovered for research purposes from the $\mathrm{Rb} \mathrm{Br}$ target solutions processed at Los Alamos for ${ }^{68} \mathrm{Ge}$. The USGS ordered $2 \mathrm{mCi}$ of the isotope. During the last fiscal year, $63 \mathrm{mCi}$ of this radioisotope were shipped to users with diverse applications. Most of these involved environmental and biological tracer studies. One physics group is using the radioisotope to perform Mossbauer measurements on ${ }^{73} \mathrm{Ge}$. The demand for ${ }^{73} \mathrm{As}$ is growing and might double by 1995. Currently, Los Alamos is an intermittent, yet the only, producer of this radionuclide. It is conceivable that demand could double again by the year 2000 .

${ }^{55} \mathrm{Fe}$-- Iron-55 is primarily used as a low-energy $\mathrm{x}$-ray source in $\mathrm{x}$-ray fluorescence spectroscopy. Although ${ }^{55} \mathrm{Fe}$ is available as a reactor-produced radionuclide, the specific activity is too low to produce high-level sources. Due to self-absorption of emitted $\mathrm{x}$-rays 
in stable iron, over $400 \mathrm{mCi}$ of ${ }^{55} \mathrm{Fe}$ must be used to obtain the same number of $\mathrm{x}$-rays from a $100 \mathrm{mCi}$ source of high-specific-activity ${ }^{55} \mathrm{Fe}$. The specific activity of ${ }^{55} \mathrm{Fe}$ produced in a reactor ranges from 16 to $25 \mathrm{Ci} / \mathrm{g} \mathrm{Fe}$, while the theoretical maximum specific activity for this isotope is $2300 \mathrm{Ci} / \mathrm{g}$. In principal, this purity of ${ }^{55} \mathrm{Fe}$ could be approached using magnesium-55 $\left({ }^{55} \mathrm{Mn}\right)$ targets in an accelerator. If high specific activity material were available, the annual world-wide demand would be 4 to $5 \mathrm{Ci}$. One vendor of sources has indicated that, if accelerator-produced material were available (allowing production of $500-\mathrm{mCi}$ sources), the annual demand would increase dramatically between now and the year 2000.

${ }^{57}$ Co- .- This isotope is used as a radiotracer in research applications and as a source for $x$-ray fluorescence spectroscopy. Current applications require that the material contain less than $0.25 \%{ }^{56} \mathrm{Co} /{ }^{58} \mathrm{Co}$, and that the specific activity be greater than 5000 $\mathrm{Ci} / \mathrm{g}$. These specifications can only be met by producing the isotope in an accelerator.

At present, the ${ }^{57} \mathrm{Co}$ is being supplied by using spare time on cyclotrons used primarily for short-lived PET isotopes. As PET grows, it is predicted that beam-time for production of non-medical isotopes such as ${ }^{57}$ Co will decrease significantly. Already, periodic serious shortages of this isotope are occurring. It has been estimated that current demand for this isotope is 8 to $10 \mathrm{Ci}$ per year, and that the NBTF would fill a large percentage of this demand. Growth potential for this isotope is unknown, but it is believed that a reliable supply would lead to an increase in demand for the radionuclide over the next 10 years.

${ }^{179} \mathrm{Ta}$-- Americium-241 $\left({ }^{241} \mathrm{Am}\right)$ is used as an $\mathrm{x}$-ray fluorescence source and in thickness gauging. It has been proposed that, despite higher cost and shorter half-life, accelerator-produced ${ }^{179} \mathrm{Ta}$ would be an advantageous substitute for ${ }^{241} \mathrm{Am}$. The advantages include: 1) discontinued use of a long-lived alpha emitter; 2) elimination of the probiems associated with transuranic waste disposal; 3 ) higher photon yields in the 55 to $60 \mathrm{keV}$ range; 4) expanded market in countries that currently ban $\left.{ }^{241} \mathrm{Am} ; 5\right)$ greater safety in production and use of the sources; and 6) easier licensing.

Since ${ }^{179} \mathrm{Ta}$ is not currently being produced for commercial use, it is difficult to assess the potential market. The current cost for ${ }^{241} \mathrm{Am}$ is about $\$ 3 / \mathrm{mCi}$ plus the costs of waste disposal. It has been suggested by one source vendor that there could be an annual demand of 10 to 15 curies, even with a per millicurie cost 3 to 5 times that of ${ }^{241} \mathrm{Am}$. To realize this, the advantages of the tantalum isotope would have to be demonstrated.

${ }^{48} \mathrm{~V}$-- Scientists working in nutrition and exvironmental chemistry have expressed an interest in the availability of a vanadium radioisotope. Vanadium- $48\left({ }^{48} \mathrm{~V}\right)$ is a gamma photon emitter well suited to the needs of these scientists. One proposed application is to use ${ }^{48} \mathrm{~V}$ (complexed into oil-soluble organic metals) to monitor the leakage of active, contaminated oils from underground storage tanks at the Hanford facility. There currently is not a large demand for ${ }^{48} \mathrm{~V}$, but there have been no major production efforts for this 
radionuclide. Future demand, though unclear today, will depend upon the success of the research exploring some of the novel applications.

${ }^{95} \mathrm{Tc},{ }^{96} \mathrm{Tc}$-- The study of technetium chemistry has been an important part of basic chemistry research since the discovery of technetium in the 1930's. In fact, many of the technetium-based radiopharmaceuticals used in medicine were developed from data derived from these basic studies. Much of this work has been done using ${ }^{99 m_{T}} \mathrm{Tc}$ from the molybdenum-99 $\left({ }^{99} \mathrm{Mo}\right) /{ }^{99 \mathrm{~m}} \mathrm{Tc}$ generator. Researchers have been interested in using other technetium radioisotopes in their work, but to date there has been no significant effort to produce other radioisotopically pure technetium nuclides. One radioisotope vendor has indicated that they receive one or two requests each month (ranging from $4 \mathrm{mCi}$ to $10 \mathrm{mCi}$ ) for radioisotopically pure ${ }^{95} \mathrm{Tc}$ that could be used as a tracer in technetium chemistry studies. The vendor also said that the current selling price for the isotope is $\$ 200 / \mathrm{mCi}$ for material contaminated with other technetium isotopes. Scientists are investigating methods of producing ${ }^{96} \mathrm{Tc}$, an radioisotope that would also fulfill the need for a radiotracer in basic technetium chemistry research. These important research radiotracers could be produced in the proposed accelerator using enriched targets. It is not possible at this time to predict the future demand for thise isotopes; however, the vendor mentioned above believes that initial sales could be on the order of $\$ 50$ thousand per year.

${ }^{139} \mathrm{Ce}$-- The nuclear power industry relies upon a certified standard solution containing ${ }^{57} \mathrm{Co}$, cerium-139 $\left({ }^{139} \mathrm{Ce}\right),{ }^{88} \mathrm{Y},{ }^{109} \mathrm{Cd},{ }^{60} \mathrm{Co}$, cesium-137 $\left({ }^{137} \mathrm{Cs}\right),{ }^{113} \mathrm{Sn}$, and ${ }^{203} \mathrm{Hg}$, to calibrate its high-purity germanium gamma detectors. The first four of these isotopes are produced using accelerators; the others are reactor produced. Recently, i.tere has been a severe shortage of radioisotopically pure ${ }^{139} \mathrm{Ce}$, with none being made in the United States. A French corporation is supplying European requirements, and apparently South Africa still makes the radioisotope but trade restrictions do not allow import to the United States. Demand for the radioisotope is relatively small, but this critical requirement for quality assurance in U.S. nuclear power plants will be lacking unless a substitute isotope is certified for the standard.

The radionuclide could easily be made via the lanthanum-139 $\left({ }^{139} \mathrm{La}\right)(p, n){ }^{139} \mathrm{Ce}$ reaction in the proposed NBTF accelerator. Depending upon price, this radioisotope would probably only gross about $\$ 10$ thousand per year given current demand. However, this is an excellent example of where a NBTF could serve an important national need.

There are certainly other radioisotopes that have significant commercial, scientific, or national security value that could be included in this list, and which would help justify the need for the proposed NBTF. This list was meant to be exemplary, not comprehensive. 


\section{PROJECTED REVENUES}

The following revenues can be projected for the first operating year of the accelerator:

\begin{tabular}{||c|c|c|c|c||}
\cline { 2 - 5 } \multicolumn{1}{c|}{} & Demand/Month & Price/mCi & $\begin{array}{c}\text { \% Supplied } \\
\text { by NBTF }\end{array}$ & $\begin{array}{c}\text { Est. Annual } \\
\text { Revenue }\end{array}$ \\
\hline${ }^{82} \mathrm{Sr}$ & $5 \mathrm{Ci}$ & $\$ 82$ & $60 \%$ & $\$ 3.0 \mathrm{M}$ \\
\hline${ }^{68} \mathrm{Ge}$ & $1 \mathrm{Ci}$ & $\$ 125$ & $100 \%$ & $\$ 1.5 \mathrm{M}$ \\
\hline${ }^{67} \mathrm{Cu}$ & $2 \mathrm{Ci}$ & $\$ 60$ & $100 \%$ & $\$ 1.44 \mathrm{M}$ \\
\hline $\begin{array}{l}\text { Other } \\
\text { commercial } \\
\text { radionuclides }\end{array}$ & & & & $\$ 0.5 \mathrm{M}$ \\
\hline $\begin{array}{l}\text { Other } \\
\text { research } \\
\text { radionuclides }\end{array}$ & & & & $\$ 0.7 \mathrm{M}$ \\
\hline \multicolumn{1}{|c|}{ TOTAL } & & & & $\$ 7.12 \mathrm{M}$ \\
\hline \hline
\end{tabular}

\section{TARGETRY RESEARCH}

Developing initial target designs and target cooling systems capable of withstanding the high temperatures induced by the high-current particle beam are essential research and development activities. Target research and development would also have to be carried out for each newly requisitioned research radionuclide proposed for investigation as a biomedical tracer. Support of this technical activity should be provided for in the core funding of the NBTF.

Research efforts, therefore, in nuclear reaction studies, excitation function measurements, and radiochemical separation methodology are essential research activities of the NBTF program. Development work is required to gain a practical knowledge in evaluating materials and other production applications. A crucial consideration in target selection is the method used to recover and purify the isotope and convert it to the desired chemical form.

In order to prepare the purest radionuclide product, isotopically enriched target materials would, in many cases, be required. Due to the significant costs of enriched stable isotope targets, the process chemistry must incorporate appropriate steps for the efficient recovery of the target element and conversion to a form suitable for reuse. 
Many factors must be considered when making decisions regarding a target for production of an isotope. Of obvious importance is the efficiency with which the isotope of interest would be produced in the target. A comprehensive knowledge of the chart of the nuclides is essential in evaluating a given target. Beyond this, the scientist must have a working understanding of particle transport concepts, cross-sections, recoil energies, and similar basic nuclear fundamentals. Research into target choice often begins with making nuclear reaction cross-section measurements on feasible target materials. Another important consideration in selecting the target is encapsulation in the accelerator beam. Factors such as physical phase at operating temperature, cooling methods, target thickness and density, and radiation effects must be considered. Research is required to gain a practical knowledge in evaluating materials and hardware for production applications. A crucial consideration associated with target selection is the method that will be used to recover and purify the isotope. The methods of separation might be chemical or physical, depending upon the natul 3 of the target. The scientist making target decisions, therefore, must have an expert knowledge of chemistry and physics. The post-irradiation physical and chemical states of both the target material and the radionuclides produced must be known in order to develop a cost-effective and efficient recovery procedure. Since many of the targets conceived for accelerator production depend upon enriched materials, it will be important to think about methods of recovery of the target material for re-use.

Regarding educational functions (to be discussed subsequently), it is apparent that a student involved in isotope production targetry could learn a great deal about nuclear science and radiochemistry, which wolild have broad application in fields needing this expertise. 


\section{SCIENTIFIC EDUCATION AND TRAINING}

The value of the diagnostic and therapeutic uses of radioisotcpe-labeled compounds to the health of the American population is well established. A recent National Academy of Science publication ${ }^{5}$ stated that we face a severe shortage of adequately trained people to meet national needs for several sectors of medicine, science, and technology. The report stated:

In most instances what is needed in basic and clinical research as well as in the radiopharmaceutical industry and in nuclear pharmacies are people whose primary specialization may be in organic (and inorganic) synthesis, analytical chemistry or biochemistry, but who also have a sound background in radiochemical techniques and instrumentation. In addition, there is a need ror a smeller number of bona fide nuclear and radiochemists to work in such areas as design of new radionuclide generators, optimization of radionuclide production at accelerators, and development of new applications....

Nuclear medicine is currently facing a shortage of organic and inorganic chemists and nuclear pharmacists who also have advanced training in nuclear and radiochemistry....

Basic and applied research in chemistry has played a major role in developing safer, more efficacious radiopharmaceuticals for nuclear medicine. The participation of chemists in this field has increased significantiy over the past two decades. The growth of the field can be attributed in large part to sustained support by the Department of Energy and by the National Institutes of Health. New developments in radiopharmaceuticals are rapidly commercialized and radiopharmaceutical chemistry has become one of the most active subdisciplines of nuclear medicine. Unfortunately, long-term programs to address the inevitable manpower shortage resulting from this rapid growth are not in place.

The report recommends the establishment of "training centers and postgraduate fellowships to support specialized education in those aspects of nuclear and radiochemis. try required by the nuclear medicine profession."

$5 \quad$ Nuclear Regulatory Commission, National Academy of Sciences. 1983. Training for Chemists in Nuclear Medicine, Nuclear Industry and Related Areas. Washington, DC: National Academy of Sciences. 
In addition to its other functions (described in The Production Facility and Research Using Radioisotopes chapters), the NBTF presents an excellent opportunity to provide a national focus for the much needed training and education of a new generation of radiochemistry students. The NBTF would provide a wide range of radionuclides, some of which are not available -- even in research quantities -- today. It is essential to design this facility to be used for all aspects of research and development in radionuclide production, tracer development and training of scientists and support staff.

The education and training activities at the NBTF are an essential feature that would focus on two aspects: 1) teaching of radionuclide production methods and 2) development of "new" radionuclides for biomedical research and technology transfer.

The training of young scientists, either as graduate students or post-doctoral scientists, would provide a desperately needed expansion of scientists trained in the basics of nuclear chemistry and radiochemistry. In addition, the training program would provide a pool of technical staff specifically knowledgeable in the production, handling and use of accelerator-produced radionuclides.

\section{PROPOSED STRUCTURE OF THE EDUCATIONAL PROGRAM}

A major function of this facility is to assure an adequate supply of well-trained chemists, pharmacists and others in the biosciences to provide the necessary expertise to deal with the broad range of radionuclides that could be produced at the NBTF. Staff members would supervise the graduate students and post-doctorals, directing them in the development of new radioisotopes and the research needed to develop targetry compatible with the size and power of the proposed facility.

An integral part of the NBTF would be laboratories, seminar rooms, and offices to support graduate students, post-doctorals, and visiting scientists who come for advanced study and research. In addition, strong cooperation with industry must be a part of this effort so that the needs of the nuclear medicine community and patients can be met expeditiously through technology transfer and the development and marketing of new products.

The educational program should be similar to the National Science Foundation (NSF) Centers of Excellence. The NBTF would be a unique facility where graduate students, post-doctoral fellows, and visiting scholars could learn and participate in state-of-the-art research and production techniques in the radiochemical sciences. Funding to support these trainees would be available from a combination of core institutional funds, training grants, and extramural research grants.

Overall direction of the educational program would be provided by an advisory committee composed of nationally recognized scientists from outside the NBTF as well as scientists at the facility. The committee would annually review the training programs, including 
course work, laboratory and research experiences, etc. It would also set criteria and pnlicy for selection of graduate, post-graduate, or other trainees to fill the funded positions. Because this is a national facility, the most qualified students and trainees would be selected from a pool of applicants from across the country.

The NBTF must have the abslity and orientation to support and educate graduate students (in MS and PhD programs) and post-doctoral fellows. The NBTF scientists must, therefore, have the qualifications to serve as advisors or co-advisors for graduate students in academic programs.

\section{FUNDING}

In order to provide a program of excellence with long-term stability, funding, salaries, and stipends for these trainees must be available at the NBTF. In addition, funds for an educational coordinator should be provided. Funding should come from three major sources:

1. Core Facility Support.

2. Extramural Support (from Government and Industry).

3. Training Programs (Government-Sponsored).

\section{Core Facility Support}

This funding would form an essential foundation for NBTF educational programs. It could be derived from several sources, but must be available on a continuing basis. For example, long-term commitment of local or state funds for the educational support would receive serious consideration in evaluation of all bids. It is estimated that $\$ 500,000$ should be committed annually to cover operating costs of the NBTF's educational component. These funds would be particularly important when the program is initiated.

\section{Extramural Support}

It would be required that NBTF scientists be active in research and maintain extramural funding from government agencies or corporations. These funds may vary from year to year, but would provide an important source of additional research and salary funds for students and trainees. Funding from corporations may be available for support of one or more trainees. Some of these funds should also be furnished by DOE.

\section{Training Programs}

Because of the unique production and research potential of the NBTF, it would be necessary to obtain training grants to expand the capacity for training graduate and postgraduate students. In addition, funds to offer specialized programs (such as summer 
programs, workshops, etc.) should be obtained by this route. The educational function would be a part of the core administration at the facility.

It must be emphasized that a high-quality educational program would provide important benefits for the nation, particularly in nuclear medicine as well as many other health and environmentally related fields. Adequate funding of this eciucational program would be a catalyst to generate national awareness and interest in radiochemistry and related applications. This would help increase the supply of trained radiation workers, which will be essential for our country to maintain its competitiveness in several scientific and technical areas (such as nuclear medicine, radiopharmaceutical chemistry, etc.) that are critically dependent upon the availability of specialists in radiochemistry. 


\section{POSSIBLE SITE SELECTION CRITERIA FOR THE NBTF}

A function of preparing the NBTF study, was to develop site selection criteria that would be offered to the DOE for its consideration. After much debate, it was concluded that the scope of recommendations should be broadly based, and that the emphasis be placed on the unique and national characteristics of such a facility. For its continued existence and future development, the NBTF should not be dependent solely on federal government financing. Instead, funding sources should include regional resources, particularly in the areas of research and education, to help support the activities of the NBTF.

\section{Criteria for NBTF Site Selection}

1. Accessibility to a national distribution center.

2. Adequate provision for radioactive waste storage and/or disposal.

3. Association with degree-granting educational institution(s).

4. Cost-sharing support (to the extent possible) from municipal government, state government, university (private educational institution), and industry.

5. Potential for academic and industrial collaboration.

6. Scientific capabilities to pursue research in new radioisotope development, radiopharmaceutical development, and application of products and services that result from the NBTF (such as nuclear physics, nuclear chemistry, radiochemistry, separations chemistry, and bioinorganic chemistry).

7. Reasonable proximity to a nuclear medicine medical facility that can be used in clinical research of new radiopharmaceuticals and that includes animal facilities for radiokinetic and radiobiologic studies. 


\section{National Biomedical Tracer Facility Advisory Committee}

An advisory committee will be appointed to oversee the education, production and research activities of the NBTF. The advisory committee's purpose will be to balance the three component activities and protect the integrity of the NBTF's mission as outlined in the feasibility study.

\section{Organization:}

Members of the advisory committee may include the director of the NBTF, the Provost/Dean of Research of the affiliated University, the Provost/Dean of Academic Affairs, the Director of Radiation Safety, and two investigators who are unaffiliated with the NBTF. Examples of an unaffiliated investigator could be a representative from the radionuclide industry, or a physician specializing in the medical uses of isotopes.

A chair will be selected by the advisory committee members and be reviewed annually. The chair will serve as the national spokesperson for the NBTF and represent the NBTF before government agencies, Congress, the press, and other public/professional entities.

A subcommittee may be appointed for production, teaching, and research to represent the three component activities. A subcommittee may be chaired by the respective member of the advisory committee. Subcommittee members may be appointed by the chair, but should also include two unaffiliated investigators.

\section{Purpose:}

The advisory committee will meet at least semi annually and will advise NBTF administration on issues regarding research, education, and production. Advisors may prioritize NBTF research activities, suggest time-lines for the production of isotopes, recommend new curriculum, or potential joint ventures. The advisory committee should be informed regarding the financial stability of the NBTF, review reports on production activity, education enrollment, and general operating status.

\section{Structure:}

\begin{tabular}{|c|c|c|}
\hline \multicolumn{3}{|c|}{ Advisory Committee } \\
\hline \multirow{2}{*}{\multicolumn{3}{|c|}{$\begin{array}{l}\text { Independent Investigator Independent Investigator } \\
\text { (Chair/Spokesperson must be appointed by membership) } \\
\text { Subcommittees }\end{array}$}} \\
\hline & & \\
\hline $\begin{array}{l}\text { Research } \\
\text { Dean of Research } \\
3 \text { Members } \\
2 \text { Unaffiliated }\end{array}$ & $\begin{array}{l}\text { Production } \\
\text { Dir. of Rad. Safety } \\
3 \text { Members } \\
2 \text { Unaffiliated }\end{array}$ & $\begin{array}{l}\text { Education } \\
\text { Dean of Academic Affairs } \\
3 \text { Members } \\
2 \text { Unaffiliated }\end{array}$ \\
\hline
\end{tabular}




\section{TABLES}


TABLE I. COMPARISON OF $100 \mathrm{MeV}$ ACCELERATOR PARAMETERS

\begin{tabular}{|l|c|c||}
\hline \multicolumn{1}{|c|}{ Item } & Cyclotron & LINAC \\
\hline Beam Type & $\mathrm{H}^{-}$ & $\mathrm{H}^{+}, \mathrm{H}^{-}$ \\
\hline Energy & $30-100$ continuous & $21-100$ incremental \\
\hline Energy Spread & $<2 \%$ & $1.5 \%$ \\
\hline Intensity & $750 \mu \mathrm{amp}$ & $750 \mu \mathrm{mp}$ \\
\hline Duty Factor & $100 \%$ & $1.5 \%$ \\
\hline Number of Beam Lines & 4 & 2 \\
\hline $\begin{array}{l}\text { Multiple Energy } \\
\text { Simultaneous Extraction }\end{array}$ & Yes (strippers) & Yes (pulse by pulse) \\
\hline Power Consumption & $420 \mathrm{~kW}$ & $420 \mathrm{~kW}$ \\
\hline Rf Amplifiers & 1 & 7 \\
\hline Machine Activation & low & very low \\
\hline Vault (Inside Dimensions) & $20 \mathrm{~m} \times 25 \mathrm{~m} \times 5 \mathrm{~m}^{*}$ & $5 \mathrm{~m} \times 45 \mathrm{~m} \times 5 \mathrm{~m}^{\star}$ \\
\hline Shielding & $3 \mathrm{~m}$ concrete & $3 \mathrm{~m}$ concrete \\
\hline Cost (Accelerator Only) & Approx. $\$ 12 \mathrm{M}$ & Approx. $\$ 12 \mathrm{M}$ \\
\hline
\end{tabular}

* Extrapolated from parameters for $70-\mathrm{MeV}$ accelerator 
TABLE II. LINAC VS. CYCLOTRON ANALYSIS

\begin{tabular}{|c|c|}
\hline LINAC & CYCLOTRON \\
\hline \multicolumn{2}{|c|}{ Advantages } \\
\hline $\begin{array}{l}\text { Dual-beam acceleration } \\
\text { Very low machine activation } \\
\text { Less stringent vacuum requirements } \\
\text { Automated control possible } \\
100 \% \text { beam extraction efficiency } \\
\text { No internal moving parts }\end{array}$ & $\begin{array}{l}\text { One Rf amplifier } \\
\text { Low machine activation } \\
\text { Flexible beam extraction with multiple } \\
\text { ports } \\
\text { DC beam } \\
\text { More mature technology } \\
\text { Availability consistent with project sche- } \\
\text { dule } \\
\text { Educational experience relevant for } \\
\text { university and industrial cyclotrons } \\
\text { Automated control proven }\end{array}$ \\
\hline \multicolumn{2}{|c|}{ Disadvantages } \\
\hline $\begin{array}{l}5 \text { or more Rf amplifiers required } \\
\text { Higher maintenance costs } \\
\text { Energy incrementally variable (21, } 39 \text {, } \\
55,70, \text { etc. } \mathrm{MeV} \text { ) } \\
\text { High instantaneous power deposition } \\
\text { (pulse-mode operation) } \\
\text { Availability not consistent with project } \\
\text { schedule } \\
\text { Complex beam switchyard }\end{array}$ & $\begin{array}{l}\text { Fixed maximum energy } \\
\text { Electromagnetic stripping limits extrac- } \\
\text { tion efficiency } \\
\text { Beam extraction foil mechanism } \\
\text { More stringent vacuum requirements }\end{array}$ \\
\hline
\end{tabular}


TABLE III. FACILITY STAFFING REQUIREMENTS

\begin{tabular}{|c|c|c|}
\hline Number of Employees & Job Title & Job Function \\
\hline 1 & Director * & management \\
\hline 1 & Physicist/Engineer * & $\begin{array}{l}\text { accelerator, beam lines, } \\
\text { targets }\end{array}$ \\
\hline 1 & Nuclear Chemist * & $\begin{array}{l}\text { cross sections, targets, } \\
\text { new applications }\end{array}$ \\
\hline 3 & Radiochemists * & radiochemical separation \\
\hline 8 & Technicians/Operators & $\begin{array}{l}\text { accelerator, beam lines, } \\
\text { targets, vacuum }\end{array}$ \\
\hline 1 & Machinist (Hot) & $\begin{array}{l}\text { target fabrication, repairs, } \\
\text { etc. }\end{array}$ \\
\hline 7 & Radiochemistry Techs & $\begin{array}{l}\text { remote radiochemical } \\
\text { separations }\end{array}$ \\
\hline 1 & Radiopharmacist * & $\begin{array}{l}\text { quality control and assur- } \\
\text { ance (QC/QA) }\end{array}$ \\
\hline 1 & Reclamation/Waste Tech & $\begin{array}{l}\text { waste packaging and } \\
\text { disposal }\end{array}$ \\
\hline 1 & Hot Cell Tech & $\begin{array}{l}\text { hot cell maintenance and } \\
\text { development }\end{array}$ \\
\hline 1 & Training Coord. * & $\begin{array}{l}\text { supervise education, } \\
\text { solicit funding }\end{array}$ \\
\hline 3 & Post-Doctoral Fellows & research and training \\
\hline 6 & Graduate Students & research and training \\
\hline 3 & $\begin{array}{l}\text { Health Physicists } \\
\text { (1 prof., } 2 \text { techs) }\end{array}$ & $\begin{array}{l}\text { environmental, health and } \\
\text { safety }\end{array}$ \\
\hline 2 & Shipping Techs & handle shipping \\
\hline 2 & Administration/Sales & $\begin{array}{l}\text { manage sales program } \\
\text { and finances }\end{array}$ \\
\hline 2 & Clerical & secretaries \\
\hline
\end{tabular}

*Ph.D. required. 
FIGURE 


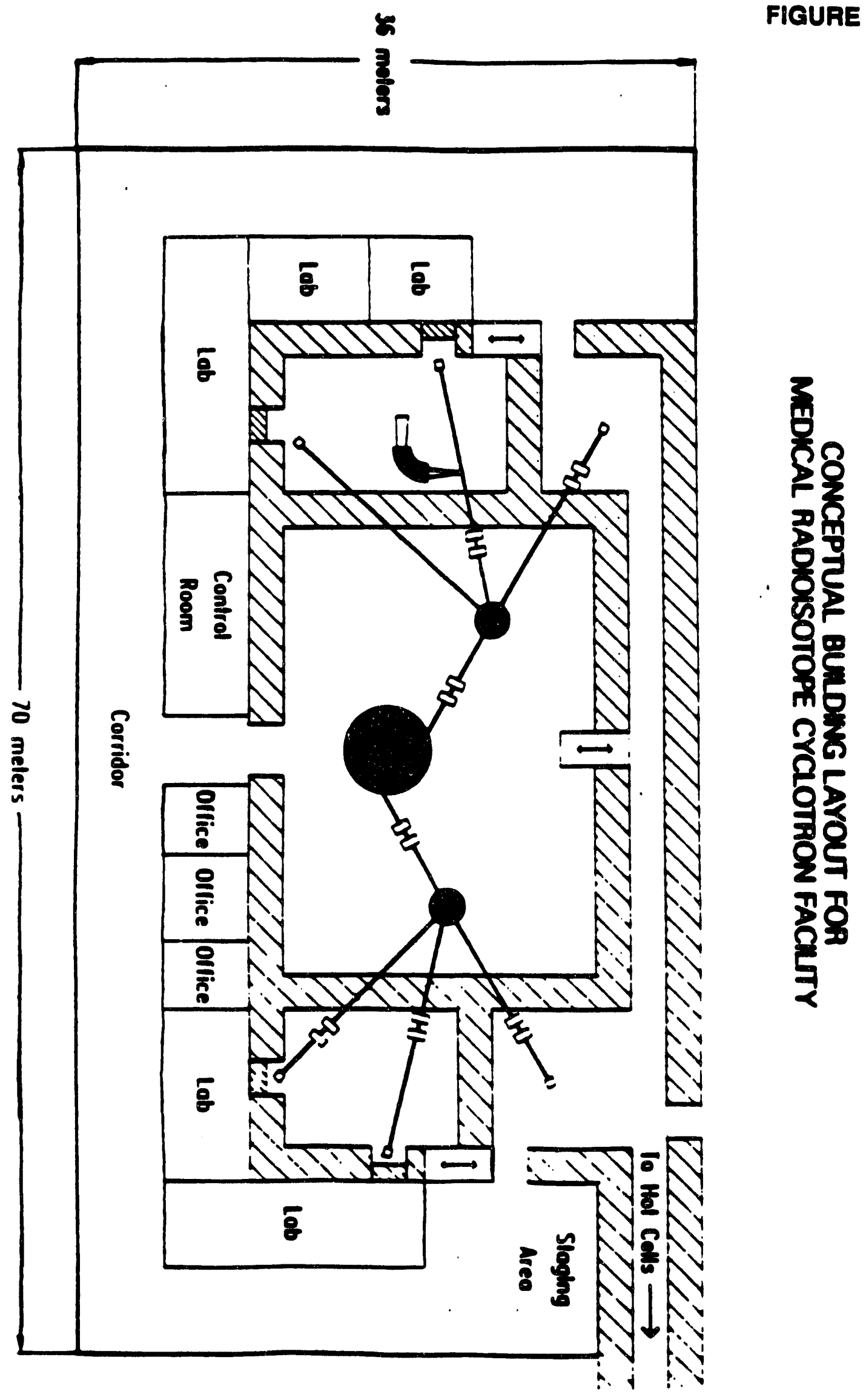




\section{APPENDICES}




\section{ACRONYMS/DOCUMENTS CITED}

AEC

BLIP

BNL

DOE

FDA

GMP

HERAC

IBA

LAMTPF

LANL

LINAC

NBTF

NDA

NSF

PET

QA

SPECT

TRIUMF

USGS
Atomic Energy Commission

Brookhaven Linac Isotope Production Facility

Brookhaven National Laboratory

Department of Energy

Food and Drug Administration

Good Manufacturing Practices

Health and Environmental Research Advisory Committee

Ion Beam Applications, Inc.

Los Alamos Meson Physics Facility

Los Alamos National Laboratory

Linear Accelerator

National Biomedical Tracer Facility

New Drug Application

National Science Foundation

Positron Emission Tomography

Quality Assurance

Single-Photon Emission Computed Tomography

Tri-University Meson Facility

United States Geological Survey
HERAC Report

Los Alamos Report
Health and Environmental Research Advisory Committee (HERAC), Office of Energy Research, U.S. Department of Energy. August, 1989. Review of the Office of Health and Environmental Research Program, Nuclear Medicine. Washington, DC: Government Printing Office.

U.S. Department of Energy, Los Alamos National Laboratory. May, 1989. Proceedings of the DOE Workshop on, The Role of a High-Current Accelerator in the Future of Nuclear Medicine. Los Alamos, New Mexico: Conference LA-11576-C. 
TABLE OF ELEMENTS

\begin{tabular}{|c|c|c|c|c|c|c|c|}
\hline Element & Symbol & $\begin{array}{l}\text { Atomic } \\
\text { N':niber }\end{array}$ & $\begin{array}{l}\text { Atomic } \\
\text { Weight }\end{array}$ & Element & Symbol & $\begin{array}{l}\text { Atomic } \\
\text { Number }\end{array}$ & $\begin{array}{l}\text { Atomic } \\
\text { Weight }\end{array}$ \\
\hline $\begin{array}{l}\text { Actinium } \\
\text { Aluminum }\end{array}$ & $A C$ & 89 & (227) & Mercury & $\mathrm{Hg}$ & 80 & 200.59 \\
\hline $\begin{array}{l}\text { Aluminum } \\
\text { Americium }\end{array}$ & A & 13 & 26.98 & Molybdenum & Mo & 42 & 95.94 \\
\hline $\begin{array}{l}\text { Americium } \\
\text { Antimony }\end{array}$ & Am & 95 & (243) & Neodymium & Nd & 60 & 144.24 \\
\hline $\begin{array}{l}\text { Antimony } \\
\text { Argon }\end{array}$ & Sb & 51 & 121.75 & Neon & $\mathrm{Ne}$ & 10 & 20.183 \\
\hline $\begin{array}{l}\text { Argon } \\
\text { Arsenic }\end{array}$ & Ar & 18 & 39.948 & Neptunium & Np & 93 & $(237)$ \\
\hline $\begin{array}{l}\text { Arsenic } \\
\text { Astatine }\end{array}$ & As & 33 & 74.92 & Nickel & $\mathrm{Ni}$ & 28 & 58.71 \\
\hline $\begin{array}{l}\text { Astatine } \\
\text { Barium }\end{array}$ & At & 85 & $(210)$ & Niobium & Nb & 41 & 92.91 \\
\hline $\begin{array}{l}\text { Barium } \\
\text { Berkelium }\end{array}$ & $\mathbf{B a}$ & 56 & 137.34 & Nitrogen & $\mathbf{N}$ & 7 & 14.007 \\
\hline $\begin{array}{l}\text { Berkelium } \\
\text { Berylium }\end{array}$ & Bk & 97 & (249) & Nobelium & No & 102 & (253) \\
\hline $\begin{array}{l}\text { Berylium } \\
\text { Bismuth }\end{array}$ & Be & 4 & 9.012 & Osmium & Os & 76 & 190.2 \\
\hline $\begin{array}{l}\text { Bismuth } \\
\text { Boron }\end{array}$ & Bi & 83 & 208.98 & $\begin{array}{l}\text { Oxygen } \\
\text { Palladium }\end{array}$ & $\begin{array}{l}0 \\
\text { Pd }\end{array}$ & $\begin{array}{c}8 \\
46\end{array}$ & $\begin{array}{l}15.9994 \\
106.4\end{array}$ \\
\hline $\begin{array}{l}\text { Boron } \\
\text { Bromine }\end{array}$ & $\begin{array}{l}\mathrm{B} \\
\mathrm{Br}\end{array}$ & $\begin{array}{c}5 \\
35\end{array}$ & $\begin{array}{l}10.81 \\
79.909\end{array}$ & $\begin{array}{l}\text { Palladium } \\
\text { Phosphorus }\end{array}$ & $\mathbf{P}$ & 15 & 30.974 \\
\hline Cadmium & Cd & 48 & 112.40 & Platinum & $\mathbf{P t}$ & 78 & 95.08 \\
\hline Calcium & $\mathrm{Ca}$ & 20 & 40.08 & Plutonium & $\mathrm{Pu}$ & 94 & (242) \\
\hline Californium & $\begin{array}{l}\text { Ct } \\
C\end{array}$ & $\begin{array}{c}98 \\
6\end{array}$ & (251) & $\begin{array}{l}\text { Polonium } \\
\text { Potassium }\end{array}$ & Po & $\begin{array}{l}84 \\
19\end{array}$ & $\begin{array}{l}(210) \\
39.102\end{array}$ \\
\hline $\begin{array}{l}\text { Carbon } \\
\text { Cerium }\end{array}$ & $\begin{array}{l}\mathrm{C} \\
\mathrm{Ce}\end{array}$ & $\begin{array}{c}6 \\
58\end{array}$ & $\begin{array}{c}12.011 \\
140.12\end{array}$ & $\begin{array}{l}\text { Potassium } \\
\text { Praseodymium }\end{array}$ & $\begin{array}{l}\mathrm{K} \\
\mathrm{Pr}\end{array}$ & $\begin{array}{l}19 \\
59\end{array}$ & $\begin{array}{l}39.702 \\
140.91\end{array}$ \\
\hline Cesium & Cs & 55 & $132.9 i$ & Promethium & Pm & 61 & $(147)$ \\
\hline Chlorine & $\mathrm{Cl}$ & 17 & 35.453 & Protactiniul., & $\mathrm{Pa}$ & 91 & (231) \\
\hline Chromium & $\mathrm{Cr}$ & 24 & 52.00 & Radium & $\mathbf{R a}$ & 88 & (226) \\
\hline Cobalt & Co & 27 & 58.93 & Radon & Rn & 86 & (222) \\
\hline Copper & $\mathrm{Cu}$ & 29 & 63.54 & Rhenium & $R_{\theta}$ & 75 & 186.23 \\
\hline Curiurn & $\mathrm{Cm}$ & 96 & $(247)$ & Rhodium & Rh & 45 & 102.91 \\
\hline Dysprosium & Dy & 66 & 162.50 & Rubidium & $\mathbf{R b}$ & 37 & 85.47 \\
\hline Einsteinium & Es & 99 & $(254)$ & Ruthenium & $\mathrm{Au}$ & 44 & 101.1 \\
\hline Ertvium & Er & 68 & 167.26 & Samarium & $\mathrm{Sm}$ & 62 & 150.35 \\
\hline Europium & Eu & 63 & 151.96 & Scandium & Sc & 21 & 44.96 \\
\hline Fermium & $\mathrm{Fm}$ & 100 & $(253)$ & Selenium & Se & 34 & 78.96 \\
\hline Fluorine & $\mathbf{F}$ & 9 & 19.00 & Silicon & $\mathbf{S i}$ & 14 & 28.09 \\
\hline Francium & $\mathrm{Fr}$ & 87 & (223) & Siver & $\mathrm{Ag}$ & 47 & 107.870 \\
\hline Gadolinium & Gd & 64 & 157.25 & Sodium & $\mathrm{Na}$ & 11 & 22.9898 \\
\hline Galium & $\mathbf{G a}$ & 31 & 69.72 & Strontium & $\mathrm{Sr}$ & 38 & 87.62 \\
\hline Germanium & $\mathrm{Ge}$ & 32 & 72.59 & Sulfur & $\mathbf{s}$ & 16 & 32.064 \\
\hline Gold & $A u$ & 79 & 196.97 & Tantalum & Ta & 73 & 180.95 \\
\hline Hafnium & $\mathrm{Hf}$ & 72 & 178.49 & Technetium & Tc & 43 & (99) \\
\hline Helium & $\mathrm{He}$ & 2 & 4.003 & Tellurium & Te & 52 & 127.60 \\
\hline Holmium & Ho & 67 & 164.93 & Terbium & $\mathrm{Tb}$ & 65 & 158.92 \\
\hline Hydrogen & $H$ & 1 & 1.0080 & Thalium & $\pi$ & 81 & 204.37 \\
\hline Indium & In & 49 & 114.82 & Thorium & Th & 90 & 232.04 \\
\hline lodine & 1 & 53 & 126.90 & Thulium & $\mathrm{Tm}$ & 69 & 168.93 \\
\hline Iridium & Ir & 77 & 192.2 & Tin & Sn & 50 & 118.69 \\
\hline Iron & $\mathrm{Fe}$ & 26 & 55.85 & Titanium & $\mathrm{Ti}$ & 22 & 47.90 \\
\hline Krypton & Kr & 36 & 83.80 & Tungsten & $\because$ & 74 & 183.85 \\
\hline Lanthanum & La & 57 & 138.91 & Uranium & $u$ & 92 & 238.03 \\
\hline Lawrencium & $L w$ & 103 & $(257)$ & Vanadium & V & 23 & 50.94 \\
\hline Lead & $\mathrm{Pb}$ & 82 & 207.19 & Xenon & $X_{e}$ & 54 & 131.30 \\
\hline Lithium & نا & 3 & 6.939 & Ytterbium & Yb & 70 & 173.04 \\
\hline Lutetium & Lu & 71 & 174.97 & Yttrium & $Y$ & 39 & 88.91 \\
\hline Magnesium & $\mathrm{Mg}$ & 12 & 24.312 & Zinc & $\mathrm{Zn}$ & 30 & 65.37 \\
\hline Manganese & $M \mathbf{n}$ & 25 & 54.94 & Zirconium & $\mathrm{Zr}$ & 40 & 91.22 \\
\hline Mendelevium & Md & 101 & (256) & & & & \\
\hline
\end{tabular}




\section{CONTRIBUTING TO THIS REPORT}

Richard A. Holmes, M.D.

Professor, Medicine, Radiology and Nuclear Engineering

University of Missouri-Columbia

Capt. William Briner, (Ret)

Associate Professor of Radiology

Duke University Medical Center

Thomas F. Budinger, M.D.

Lawrence Berkley _ab

University of California - Berkley

William Eckelman, Ph.D.

Department of Nuclear Medicine

National Institutes of Health

Iotin Kuranz, Ph.D.

Chairman of the Board

Niedi-Physics, Inc.

Joinn McAfee, M.D.

Professor of Radiology

George Washirıton University Medical

Certer

Darrell Mclndoe, M.D.

Nuclear Medicine Physician

St. Joseph Hcspital

Harold A. O'Brien, Jr., Ph.D.

Scientific Staff Member

Los Alamos National Laboratory

Richard C. Reba, M.D.

Professor of Radiology and Medicine

Director of Nuclear Medicine

George Washington University Medical

Center

Wynn A. Volkert, Ph.D.

Associate Career Research Scientist

Harry S. Truman VA Hospital

Professor of Radiology

University of Missouri - Columbia
Henry N. Wagner, Jr., M.D.

Professor of Medicine, Radiology and Radiation Health Sciences

The John Hopkins Medical Institutions

Arthur Weis

Chairman and President

Capintec, Inc.

Michael J. Welch, Ph.D.

Professor of Radiology

Director, Division of Radiation Science

Washington University Medical School

Alfred P. Wolf, Ph.D.

Director Cyclotron - PET Program

Brookhaven National Laboratcries

Robert W. Atcher, Ph.D.

Department of Chemistry

Argonne National Laboratory

Donald Erb

Director, Isotope Production and Distribution

U.S. Department of Energy

Leonard E. Mausner, Ph.D.

Medical Department

Brookhaven National Laboratory

David Moody, Ph.D.

Los Alamos National Laboratory

Eugene Peterson, Ph.D.

Los Alamos National Laboratory

Kristen D.W. Morris

Director of Government Relations

ACNP/SNM

Sharon Dobson

Administrative Assistant

ACNP/SNM 

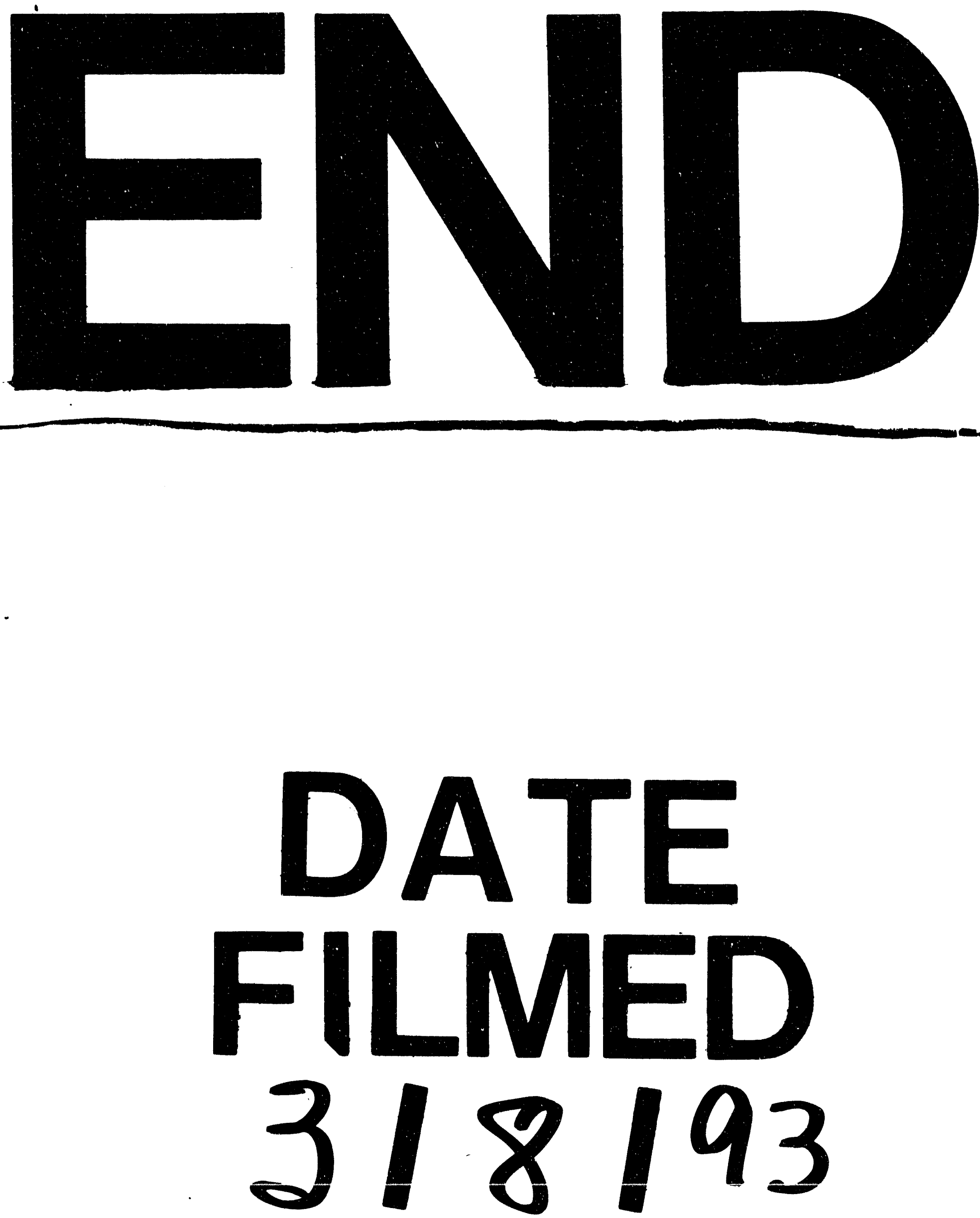

93 
